\title{
Endemic acinetobacter in intensive care units: Epidemiology and clinical impact
}

\author{
L Dijkshoorn, R van Dalen, A van Ooyen, D Bijl, I Tjernberg, M F Michel, \\ A M Horrevorts
}

Department of Clinical Microbiology, University Hospital Rotterdam, The Netherlands L Dijkshoorn M F Michel

Department of Intensive Care, University Hospital Nijmegen, The Netherlands $R$ van Dalen

Bioinformatica Group, University of Utrecht, The Netherlands A van Ooyen

Department of Medical Microbiology, University Hospital Nijmegen, The Netherlands A M Horrevorts D Bijl

Department of Medical Microbiology, Malmö General Hospital, Sweden I Tjernberg

Correspondence to: Dr L Dijkshoorn Department of Medical Microbiology, University Hospital Leiden, Building 1 LA-P, PO Box 9600, 2300 RC Leiden, 2300 RC Leiden,
The Netherlands

\begin{abstract}
Aims-To assess whether Acinetobacter isolates obtained over 20 months in a tertiary care hospital were epidemiologically related; to establish the clinical importance of the organisms; and to identify the isolates according to the
\end{abstract} recent taxonomy.

Methods-Fifty eight Acinetobacter isolates from 49 patients collected during 1984 and 1985 were investigated. Most isolates were from respiratory tract specimens from intensive care patients. The organisms were typed by cell envelope protein electrophoresis and by a quantitative carbon source growth assay; patients' charts were reviewed to differentiate between colonisation and infection; representative isolates were identified to species level by DNA-DNA hybridisation.

Results-Twelve protein profiles were distinguished in the isolates. Forty two isolates were of the same protein profile (profile I); other profiles were observed in a few or single isolates. Cluster analysis of carbon source growth divided profile I isolates into two groups-one of isolates from 1984 and one from 1985. They were identified as $A$ baumannii and associated with infections in eight patients. Four other infections were caused by acinetobacters with other protein profiles (three of $A$ baumannii; one of the unnamed DNA group 3).

Conclusions-Apart from sporadic strains, two strains of the same protein profile, but distinguishable by carbon source growth, were successively endemic. Cluster analysis was a valuable tool in the interpretation of typing and epidemiological data. The 12 (28\%) infections of Acinetobacter in 43 patients in intensive care suggest that the presence of these organisms in wards of severely ill patients should be a cause of concern.

(F Clin Pathol 1993;46:533-536)

Acinetobacters have been occasionally involved in serious infections in hospitals. ${ }^{1}$ Many outbreaks of colonisation of patients in intensive care units with highly resistant Acinetobacter strains, however, have been reported. ${ }^{2-5}$

Several methods have been used for epidemiological typing of acinetobacters, including biotyping, ${ }^{6}$ antibiotic susceptibility and plasmid typing, ${ }^{5}$ whole cell and cell envelope protein electrophoresis, ${ }^{78}$ a quantitative carbon source growth assay ${ }^{9}$ and phage typing. ${ }^{10}$ Differences between strains can be small and the combined use of methods for epidemiological typing has been advocated..$^{10}$

Protein electrophoresis ${ }^{8}$ and carbon source growth ${ }^{9}$ were used to investigate a large number of isolates from intensive care units to establish whether a single strain was predominant. The clinical impact of the outbreak was also analysed and representative isolates were identified by DNA-DNA hybridisation according to the recent classification. ${ }^{11}$

\section{Methods}

Acinetobacter strains were isolated from clinical specimens from 43 patients in four intensive care units and six patients in other wards of a tertiary care hospital. The 58 isolates (37 respiratory; 12 urine; nine other specimens) were identified to the genus Acinetobacter by conventional methods ${ }^{12}$ and were glucose acidifying.

Cell envelope protein sodium dodecyl sulphate-polyacrylamide gel electrophoresis (SDS-PAGE) was performed as described before $^{8}$ with minor modifications. ${ }^{13}$

The quantitative bacterial dot method described by Tjernberg et al was used. ${ }^{14}$ The reference strains for the DNA groups were those of a previous DNA hybridisation study, ${ }^{15}$ as were the procedures for isolation of reference DNA and labelling with ${ }^{125}$ I.

The strains were differentiated according to their ability to grow on 10 different carbon sources in a standardised, quantitative microassay, which has already been described. ${ }^{9}$

Cluster analysis reveals the most striking pattern of variation. The mean city block distance $^{16}$ was used to calculate similarities between isolates in carbon source utilisation, and Ward's agglomerative method ${ }^{17}$ was used for forming clusters. The groupings obtained were compared with groupings based on other features, including origin, moment of sampling, and protein profile.

Charts of patients from whom Acinetobacter were isolated during their stay in intensive care were inspected retrospectively for differentiation between colonisation and infection using criteria developed by the Centers for Disease Control (Atlanta). ${ }^{18}$ 


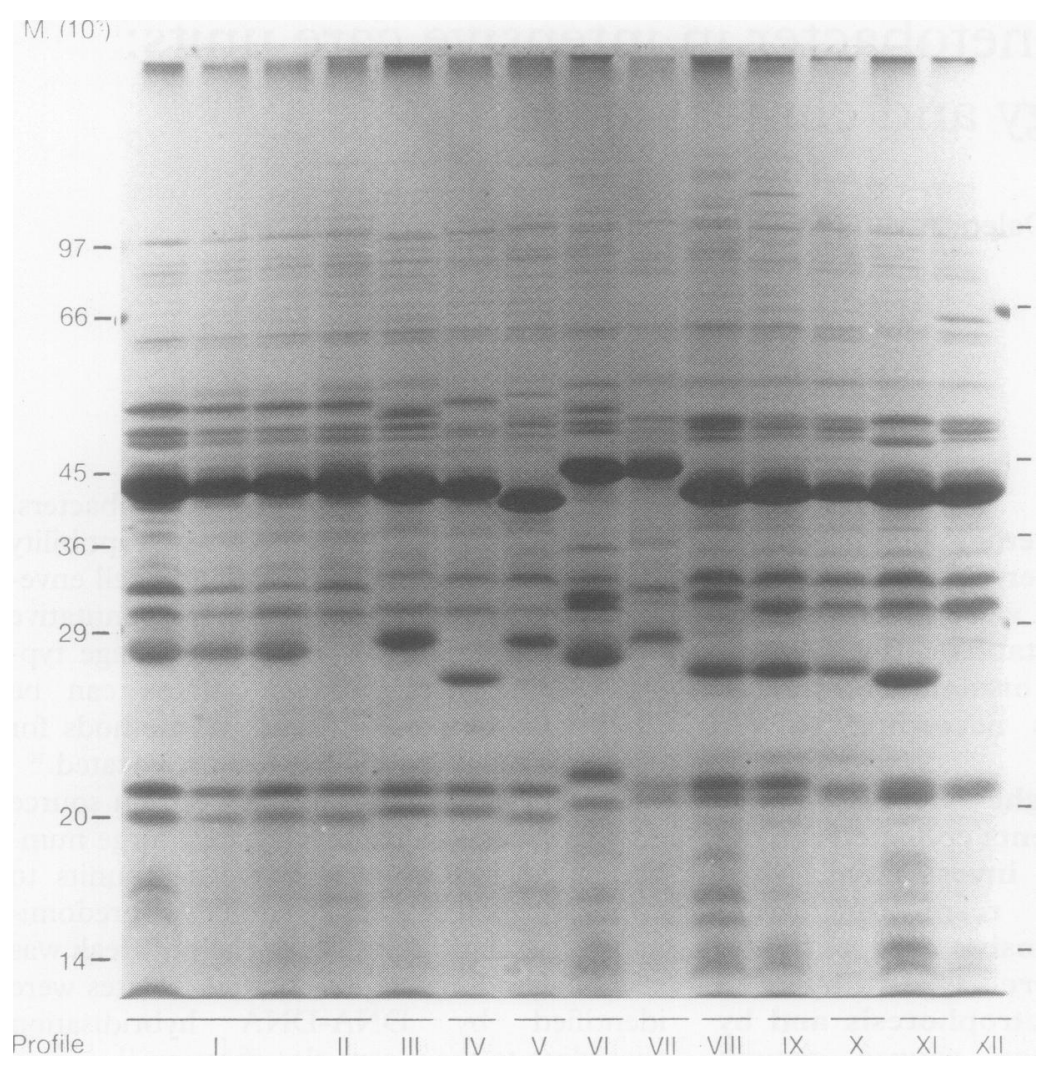

Figure 1 Cell envelope protein SDS-PAGE profiles of Acinetobacter isolates from different patients. $M_{r}$, relative apparent molecular weight.

\section{Results}

Fifty isolates of Acinetobacter were from 41 patients in three of the four intensive care units and most were from bronchial secretions.

The protein profiles were characterised by 30-50 bands of different staining intensity in apparent molecular weight range $\left(M_{\mathrm{r}}\right)$ 14-100 kilodaltons. Twelve different profiles were observed, coded I-XII (fig 1). Profiles I and II were indistinguishable, except for one band ( $M_{r} 28$ kilodaltons) missing in profile II. Profiles VIII-XII were very similar but not identical. The prevalence of the profiles and their distribution in the specimens is shown in the table. Forty two isolates belonged to protein profile I and most of these were observed in bronchial secretions. Other

Prevalence of cell envelope protein SDS-PAGE profiles in specimens and DNA-DNA hybridisation groups of Acinetobacter associated with profiles

\begin{tabular}{|c|c|c|c|c|c|c|}
\hline \multirow[b]{2}{*}{ Profile } & \multicolumn{5}{|c|}{ Specimens } & \multirow[b]{2}{*}{$D N A$ group * } \\
\hline & Blood & $\begin{array}{l}\text { Cerebrospinal } \\
\text { fluid }\end{array}$ & $\begin{array}{l}\text { Bronchial } \\
\text { secretion }\end{array}$ & Urine & $\begin{array}{l}\text { Other } \\
\text { specimenst }\end{array}$ & \\
\hline I & & 1 & 27 & 9 & 5 & $2(A$ baumannii $)$ \\
\hline II & & & 3 & 1 & & \\
\hline III & & & 1 & & & 2 \\
\hline IV & & & 1 & & & \\
\hline $\mathrm{V}$ & 1 & & & & & \\
\hline VI & & & & & 1 & 1 (A calcoaceticus) \\
\hline VII & & & 1 & & & 3 \\
\hline VIII & & & 1 & 1 & & 3 \\
\hline IX & & & 2 & & & 3 \\
\hline $\mathrm{x}$ & & & & 1 & & 3 \\
\hline XI & & & & & 1 & 3 \\
\hline XII & & & 2 & & & 3 \\
\hline
\end{tabular}

$\dagger$ Six from wounds, one insertion site drain.

*Investigated for seven isolates of profile I and for one isolate of each other profile. profiles were seen in single or in a few strains.

Seven isolates allocated to protein profile I and one isolate of each of the other profiles were identified by DNA-DNA hybridisation. The isolates of profiles $\mathrm{I}-\mathrm{V}$ tested belonged to DNA group 2 ( $A$ baumannii). The isolate of profile VI was identified as DNA group 1 ( $A$ calcoaceticus), those of profiles VII-XII as DNA group 3 (table). The results of the cluster analysis of the carbon source growth data are shown in fig 2 . Three clusters were distinguished: 27 isolates (cluster I) of protein profile I were isolated in 1984 in the intensive care units and in other wards, 12 isolates (cluster II), also of protein profile group I, were recovered in 1985 from eight patients during their stay in intensive care; cluster III comprised isolates of a variety of protein profiles obtained in 1984 and in 1985 in different wards. These results indicate that two different protein profile I strains were successively endemic. This was corroborated by the finding that the 1985 isolates were more resistant to antibiotics (quinolones) than the 1984 isolates (derived from minimal inhibitory concentrations; data not shown).

In 31 of the 43 patients in intensive care the presence of the acinetobacters was interpreted as colonisation, while for the remaining $12(28 \%)$ patients, the organisms were associated with infection: one isolate with bacteriaemia ( $A$ baumannii, profile $\mathrm{V}$ ), one isolate with meningitis ( $A$ baumannii, profile $\mathrm{I}$ ), three with pneumonia ( $A$ baumanii, profiles I $(\mathrm{n}=2)$ and III $(\mathrm{n}=1)$, and seven with tracheobronchitis ( $A$ baumannii, profile I $(\mathrm{n}=5)$, profile IV $(\mathrm{n}=1)$, and the unnamed DNA group $3(n=1)$ ).

\section{Discussion}

Numerous reports of epidemic spread of Acinetobacter in hospital wards have appeared, ${ }^{2-5}$ and in two outbreaks the concurrent spread of different strains has been notified. ${ }^{35}$ Our results show that protein electrophoresis, although found to be useful in previous studies, ${ }^{49}$ may not always be sufficient for the identification of Acinetobacter strains. Except for strains with rare protein profiles, combinations of typing methods may be needed, and results have to be judged in narrow association with epidemiological data. For this, cluster analysis could be a valuable tool.

At least 17 DNA hybridisation groups (genomic groups) can be distinguished within the genus Acinetobacter. ${ }^{11}$ The groups 1 ( $A$ calcoaceticus), 2 ( $A$ baumannii), and the unnamed groups 3 and 13 are genetically and phenotypically closely related. ${ }^{15}$ For groups 1-12, a phenotypic identification scheme has been described. ${ }^{6}$ DNA-DNA hybridisation, however, is needed for unambiguous identification of acinetobacters to DNA group level. ${ }^{19}$ The seven protein profile $\mathrm{I}$ isolates tested were all DNA group 2 ( $A$ baumannii). It was assumed that isolates of a common, indistinguishable protein profile belong to the same DNA group and, therefore, only one 
Figure 2 Dendrogram of cluster analysis of carbon source growth data. Horizontal axis: dissimilarities at which strains are grouped, determined by Ward's criterion and based on mean city block distance. Arrows denote the cutting level for separating main clusters.

Vertical axis: isolates arranged according to their $C$-growth similarities. Patients are numbered 1-49 and suffixes $a, b$, and $c$ indicate multiple

Acinetobacter isolates from single patients. IC

intensive care units; $O W$, other wards; $m / y$, month and year of isolation.

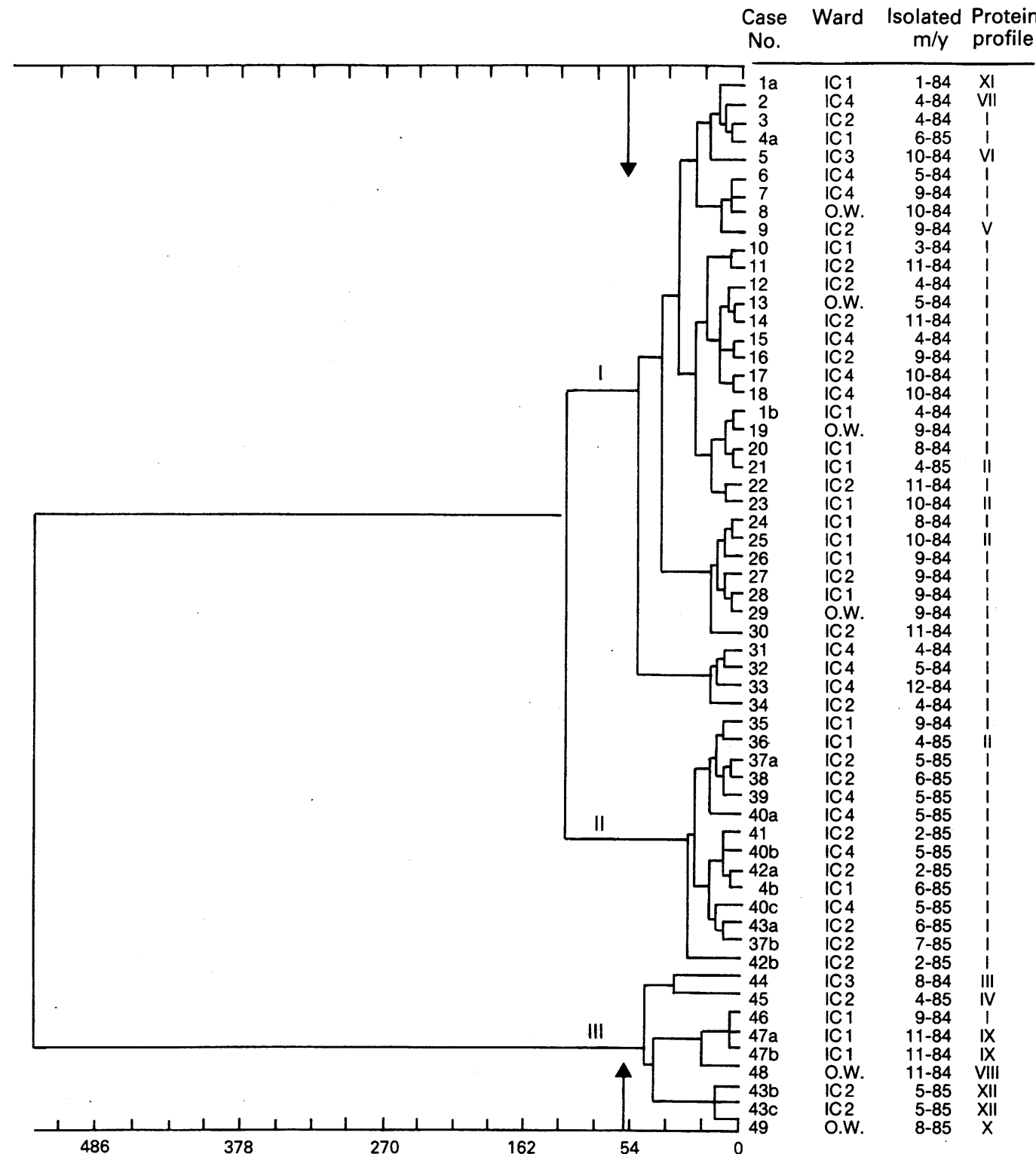

isolate of the other profiles was investigated by DNA-DNA hybridisation. The organisms of profiles II-V were also identified as DNA group 2 ( $A$ baumannii), the group most commonly associated with nosocomial infections. ${ }^{11}$ With the exception of one isolate, isolates of the remaining profiles were identified as DNA group 3. This group was rare in France, ${ }^{6}$ but was common in Sweden. ${ }^{15}$

Acinetobacters are, typically, opportunistic organisms of low virulence, but they may contribute, in mixed culture, to the virulence of other species. ${ }^{20}$ Severe infections with these organisms are more common than usually appreciated, especially in very ill inpatients. ${ }^{1}$ In the present study 12 of $43(28 \%)$ patients in intensive care with Acinetobacter were actually clinically infected, but seven of these had tracheobronchitis, which is a minor infection related to endotracheal intubation. Eight of the 12 infections were associated with endemic multiresistant organisms of protein profile I of DNA group 2 (A baumannii). The findings suggest that the presence of these organisms in wards should be a cause of concern.
This work was supported by grant 28-1070 from the "Praeventiefonds" of The Netherlands. We thank Mrs M Theuns for technical assistance, Dr P Hogeweg for helpful discussions, and Dr T L Pitt for critical review of the manuscript.

1 Glew RH, Moellering RC, Kunz LJ. Infections with Acinetobacter calcoaceticus (Herellea vaginicola): clinical and laboratory studies. Medicine 1977;56:79-97.

2 Bergogne-Bérézin E, Joly-Guillou ML, Vieu JF. Epidemiology of nosocomial infections due to Acinetobacter calcoaceticus. F Hosp Infect 1987;10 105-13.

3 Hartstein AI, Rashad AL, Liebler JM, et al. Multiple intensive care unit outbreak of Acinetobacter calcoaceticus subspecies anitratus respiratory infection and colonization associated with contaminated, reusable ventilator circuits and resuscitation bags. $A m \mathcal{F} M e d$ 1988;85:624-31.

4 Crombach WHJ, Dijkshoorn L, van Noort-Klaassen $M$, Niessen J, van Knippenberg-Gordebeke G. Control of an epidemic spread of a multi-resistant strain of an epidemic spread of a multi-resistant strain of Acinetobacter calcoaceti

5 Vila J, Almela M, Jimenez de Anta MT. Laboratory investigation of hospital outbreak caused by two different multiresistant Acinetobacter calcoaceticus subsp. anitratus strains. F Clin Microbiol 1989;27:1086-9.

6 Bouvet PJM, Grimont PAD. Identification and biotyping of clinical isolates of Acinetobacter. Ann Inst Pasteur/ Microbiol 1987;138:569-78.

7 Alexander $M$, Ismail F, Jackman PJH, Noble WC. Fingerprinting Acinetobacter strains from clinical 
sources by numerical analysis of electrophoretic protein patterns. $₹$ Med Microbiol 1984;18:55-64.

8 Dijkshoorn L, Michel MF, Degener JE. Cell envelope protein profiles of Acinetobacter calcoaceticus strains isolated in hospitals. $\mathcal{F}$ Med Microbiol 1987;23:313-9.

9 Dijkshoorn L, van Ooyen A, Hop WCJ, Theuns M, Michel MF. Comparison of clinical acinetobacter strains using a carbon source growth assay. Epidemiol Infect 1990;104:443-53.

10 Bouvet PJM, Jeanjean S, Vieu JF, Dijkshoorn L. Species, biotype, and bacteriophage type determinations compared with cell envelope protein profiles for typing pared with cell envelope protein profiles for typin
Acinetobacter strains. $\mathcal{F}$ Clin Microbiol 1990;28:170-6.

11 Grimont PAD, Bouvet PJM. Taxonomy of Acinetobacter In: Towner $\mathrm{KJ}$, Bergogne-Bérézin $\mathrm{E}$, Fewson $\mathrm{CA}$, eds. The biology of Acinetobacter. New York: Plenum Press, 1990:25-36.

12 Cowan ST, Steel KG. Manual for the identification of medical bacteria. 2nd edn. Cambridge: Cambridge University Press, 1974.

13 Dijkshoorn L, Tjernberg I, Pot B, Michel MF, Ursing J, Kersters $\mathrm{K}$. Numerical analysis of cell envelope protein profiles of Acinetobacter strains classified by DNA-
DNA hybridization. Syst Appl Microbiol 1990;13: 338-44.

14 Tjernberg I, Lindh E, Ursing J. A quantitative bacterial dot method for DNA-DNA hybridization and its correlation to the hydroxyapatite method. Curr Microbiol 1989;18:77-81.

15 Tjernberg I, Ursing J. Clinical stains of Acinetobacter classified by DNA-DNA hybridization. APMIS 1989; 97:595-605.

16 Everitt, B. Cluster analysis. 2nd edn. New York: Halsted Press, 1980:9-22.

17 Ward JH. Hierarchical grouping to optimise an objective function. $₹$ Am Stat Ass 1963;58:236-44.

18 Garner JS, Jarvis WR, Grace Emori T, Horan TC, Hughes JM. CDC definitions for nosocomial infections, 1988. Am $\mathcal{F}$ Infect Control 1988;16:128-40.

19 Gerner-Smidt P, Tjernberg I, Ursing J. Reliability of phenotypic tests for identification of Acinetobacter species. $\mathcal{f}$ Clin Microbiol 1991;29:277-82.

20 Obana Y. Pathogenic significance of Acinetobacter calcoaceticus: analysis of experimental infection in mice. Microbiol Immunol 1986;30:645-57. 